JURNAL Midwifery Update (MU)

http://jurnalmu.poltekkes-mataram.ac.id/index.php/jurnalmu

e-ISSN: 2684-8511 (Online)

\title{
FAKTOR-FAKTOR YANG MEMPENGARUHI KEINGINAN MEMILIKI ANAK LEBIH DARI DUA DI NUSA TENGGARA BARAT
}

\author{
${ }^{1}$ Baiq Nining Handayani, ${ }^{2}$ M. Ikhsany Rusyda \\ ${ }^{1}$ Perwakilan BKKBN Provinsi NTB \\ ${ }^{2}$ Badan Pusat Statistik Provinsi NTB
}

\begin{abstract}
Abstrak
Penelitian ini bertujuan untuk mengetahui factor-faktor yang mempengaruhi keinginan memiliki anak lebih dari dua di Nusa Tenggara Barat. Data yang digunakan adalah Survey Penduduk Antar Sensus (SUPAS) Tahun 2015 dengan unit analisis Wanita Usia Subur yang sudah menikah usia 10-54 tahun. Analisis dilakukan dengan metode regresi logistik biner. Hasil analisis menunjukkan bahwa wanita usia subur di Nusa Tenggara Barat yang telah memiliki dua anak sebagian besar masih menginginkan anak yang ketiga. Semakin lama ibu menikah dan semakin tua usia ibu, kecenderungan untuk menambah anak lagi setelah memiliki dua anak semakin berkurang. Penggunaan $\mathrm{KB}$ dan daerah tempat tinggal menunjukkan adanya perbedaan keinginan untuk menambah anak lagi setelah memiliki dua anak. Kelompok umur, jenis kelamin anak, lama dalam ikatan perkawinan, penggunaan alat/cara KB dan pulau tempat tinggal berpengaruh signifikan terhadap keinginan memiliki anak lebih dari dua di Nusa Tenggara Barat.
\end{abstract}

Kata Kunci : Keinginan memiliki anak, lebih dari dua

\section{FACTORS AFFECTING THE DESIRE OF MORE THAN TWO CHILDREN IN WEST NUSA TENGGARA}

\section{Abstract}

The aim of this study is to determine the factors that influence women's desire to have more than two children in West Nusa Tenggara. The data used is the 2015 Intercensal Population Survey (SUPAS) with the unit of analysis is married women aged 10-54 years and analyzed with binary logistic regression method. The analysis shows that most women of childbearing age in West Nusa Tenggara who already have two children still want to have children. The longer the mother gets married and the older the mother's age, the tendency to have more children decreases. The use of contraception and the condition around residential areas shows differences in the desire to have more children. Age group, sex of children, length of marriage, use of contraception 
methods, and place of living have significant effects on the desire to have more than two children in West Nusa Tenggara.

Keywords: Desire to have children; more than two

\section{Pendahuluan}

Salah satu komponen pertumbuhan penduduk di suatu daerah adalah fertilitas (tingkat kelahiran). Provinsi NTB merupakan salah satu Provinsi dengan jumlah penduduk yang cukup besar. Proyeksi Penduduk NTB periode 2010-2020 terjadi peningkatan jumlah penduduk dari 4.516.062 jiwa menjadi 5.125.622. Selain itu, Total Fertility Rate (TFR) mengalami Stagnan di angka 2,8 meskipun kesertaan ber KB meningkat dari 54,9\% menjadi 56\%, TFR 2017 terjadi penurunan menjadi $2,5 .^{8}$

Salah satu faktor yang mempengaruhi Total Fertility Rate (TFR) adalah jumlah anak yang diinginkan. Jumlah anak yang diinginkan sebenarnya bukan merupakan variabel langsung yang berhubungan dengan fertilitas, namun berhubungan dengan variabel yang memengaruhi salah satu variabel antara, yaitu pengaturan kelahiran. Menurut Singh et al. (2010) banyak keluarga akan terus memiliki anak setelah mencapai ukuran keluarga yang diinginkan. Keputusan untuk memiliki sejumlah anak adalah sebuah pilihan, yang mana pilihan tersebut sangat dipengaruhi oleh beberapa hal. ${ }^{9}$ Pertama, kunjungan petugas KB yang memberikan motivasi mengenai norma keluarga kecil bahagia sejahtera atau NKKBS. ${ }^{10}$ Kedua, kecenderungan orang tua dalam memaknai kehadiran anak (nilai anak). Rahayu (2009) menemukan bahwa faktor-faktor yang memengaruhi jumlah anak yang diinginkan oleh keluarga Pasangan Usia Subur (PUS) yang bekerja adalah jumlah jam kerja, status sosial ekonomi, dan usia menikah pertama istri berpengaruh signifikan terhadap jumlah anak yang diinginkan. ${ }^{11}$ Tujuan dari penelitian ini adalah untuk mengetahui faktor-faktor yang mempengaruhi keinginan memiliki anak lebih dari 2 di Nusa Tenggara Barat.

\section{Metode}

Penelitian ini menggunakan data sekunder dari Survey Penduduk Antar Sensus (SUPAS) propinsi NTB 2015 dengan unit analisis Wanita Usia Subur (WUS) yang sudah menikah usia 1054 tahun yang berstatus pernah kawin dengan jumlah anak masih hidup. Metode analisis yang digunakan adalah analisis deskriptif dan inferensial yaitu model regresi logistik biner. 


\section{Hasil Dan Pembahasan}

Tabel 1. Distribusi Frekuensi Jumlah Anak Yang Diinginkan Menurut Variabel Sosial Demografi

\begin{tabular}{|c|c|c|}
\hline KARAKTERISTIK & JUMLAH & $\%$ \\
\hline \multicolumn{3}{|l|}{ Daerah Tempat Tinggal } \\
\hline Perkotaan & 660 & 52,55 \\
\hline Perdesaan & 596 & 47,45 \\
\hline \multicolumn{3}{|l|}{ Tingkat Pendidikan } \\
\hline Tidak Sekolah & 55 & 4,38 \\
\hline Sekolah Dasar & 329 & 26,19 \\
\hline Menengah & 636 & 50,64 \\
\hline Perguruan Tinggi & 236 & 18,79 \\
\hline \multicolumn{3}{|l|}{ Kelompok Umur } \\
\hline $15-19$ & 198 & 15,8 \\
\hline $20-24$ & 173 & 13,8 \\
\hline $25-29$ & 199 & 15,8 \\
\hline $30-34$ & 174 & 13,9 \\
\hline $35-39$ & 200 & 15,9 \\
\hline $40-44$ & 172 & 13,7 \\
\hline $45-49$ & 140 & 11,1 \\
\hline Total & 1256 & 100,0 \\
\hline
\end{tabular}

Sumber Data : Supas Prov. NTB, 2015 yang telah diolah

Di Nusa Tenggara Barat, sebagian besar WUS tinggal di daerah perkotaan dibandingkan perdesaan. Dengan tingkat pendidikan menengah (50,64\%), tamat SD (26,19\%), Perguruan Tinggi (18,79\%) dan yang paling rendah adalah tidak sekolah $(4,38 \%)$. hal ini berarti bahwa program wajib belajar minimal 9 tahun yang dicanangkan oleh Kementrian Pendidikan dan Kebudayaan berhasil, akan tetapi utnuk meningkatkan kualitas sumber daya manusia, maka pemerintah tetap menggalakkan pendidikan yang setinggi-tingginya. Berdasarkan kelompok umur, persentase yang paling besar adalah berada pada kelompok umur 35-39 tahun. Dimana pada kelompok umur teersebut berada pada kelompok umur produktif untuk hamil dan melahirkan. Fasli Djalal menemukan bahwa ada beberapa kelompok umur tertentu masa reproduksi sehat seperti usia kurang dari 20 tahun adalah masa reproduksi muda (bahaya untuk hamil dan melahirkan, sebaiknya ditunda dulu), usia 20-30 tahun masa reproduksi sehat (silahkan punya anak) dan masa reproduksi tua (usia 30-35 tahun) jangan lagi punya anak karena mengurus balita dan diatas 35 tahun . 
Tabel 2. Distribusi Frekuensi Jumlah Anak Yang Diinginkan Menurut Tingkat Kesehateraan dan Status Bekerja

\begin{tabular}{lcc}
\hline \multicolumn{1}{c}{ KARAKTERISTIK } & JUMLAH & $\mathbf{\%}$ \\
\hline Tingkat Kesejahteraan & & \\
Sangat Miskin & 379 & 30,18 \\
Miskin & 273 & 21,74 \\
Menengah & 239 & 19,03 \\
Kaya & 185 & 14,73 \\
Sangat Kaya & 180 & 14,33 \\
\hline Status Bekerja & & \\
Tidak Bekerja & 592 & 47,13 \\
Bekerja & 664 & 52,87 \\
\hline Total & $\mathbf{1 2 5 6}$ & $\mathbf{1 0 0 , 0 0}$ \\
\hline
\end{tabular}

Tingkat kesejahteraan sangat miskin mempunyai persentase paling tinggi dibandingkan dengan tingkat kesejahteraan lainnya. Tingkat kesejahteraan sangat berpengaruh pada berbagai sektor kehidupan seperti ekonomi, pendidikan dan kesehatan, karena ketiga hal ini sangat menentukan kualitas sumber daya manusia. Status bekerja berpengaruh terhadap tingkat kesejahteraan. Berdasarkan status bekerja, Sebagian besar Wanita Usia Subur (WUS) bekerja dibandingkan dengan yang tidak bekerja. Salah satu upaya untuk meningkatkan kesejahteraan keluarga adalah dengan bekerja. Banyaknya WUS yang bekerja menunjukkan bahwa banyak WUS yang produktif untuk meningkatkan kesejahteraan keluarga.

Proporsi Jumlah Anak Yang Diinginkan Menururt Daerah Tempat Tinggal

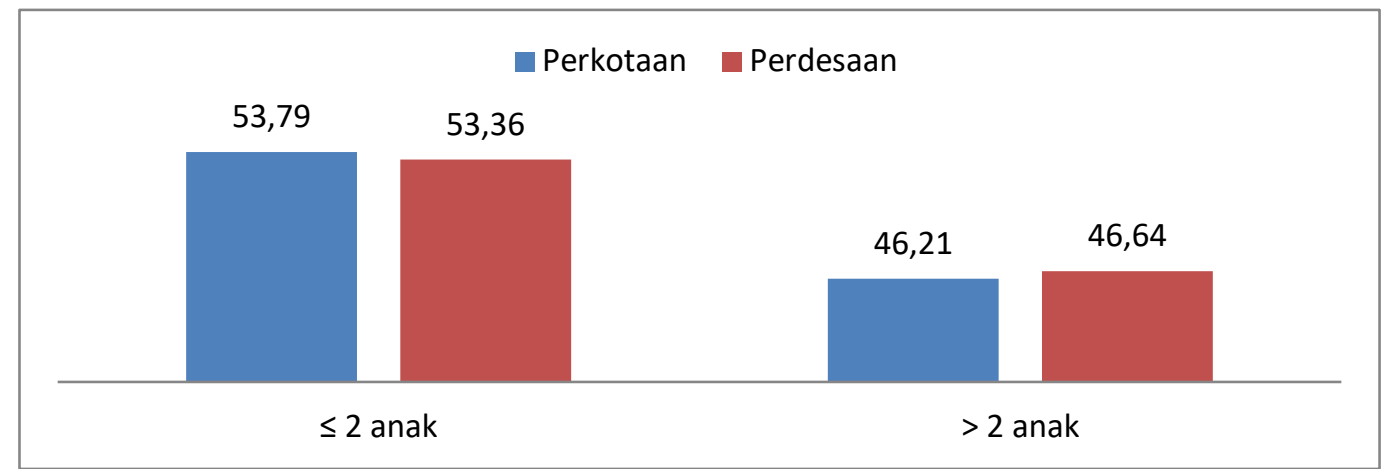

WUS yang menginginkan jumlah anak ideal $\leq 2$ tidak mempunyai perbedaan yang signifikan (sebesar 53 persen). Antara WUS yang tinggal di daerah perkotaan maupun yang tinggal di perdesaan. Hal ini menunjukkan adanya kecenderungan yang relatif sama antara wanita di perkotaan maupun diperdesaaan terkait jumlah anak yang diinginkan. 
Proporsi Jumlah Anak Yang Diinginkan Menurut Tingkat Pendidikan,Prov NTB, 2015
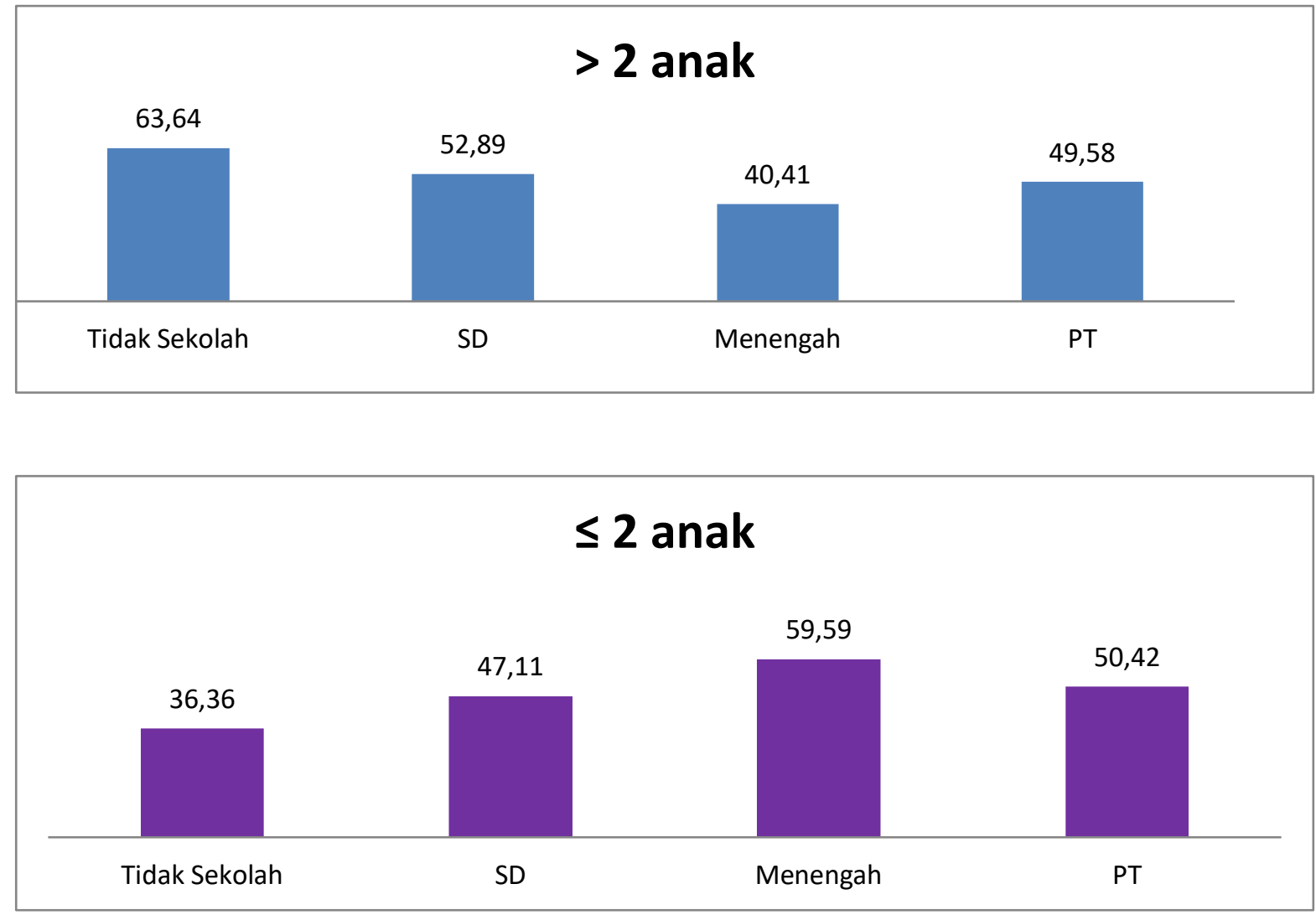

Sumber Data SDKI Prov. NTB yang telah diolah, 2017

WUS yang berpendidikan menengah ke atas dan menginginkan jumlah anak $\leq 2$ anak mempunyai proporsi lebih banyak dibandingkan dengan WUS yang menginginkan lebih dari 2 anak. WUS yang menginginkan jumlah anak $\leq 2$ cenderung lebih besar pada WUS yang berpendidikan rendah yaitu WUS yang tidak sekolah, proporsi WUS yang menginginkan anak lebih dari 2 mencapai 64 persen. Penelitian Aditya (2011) menunjukkan tingkat pendidikan orang tua memberi gambaran adanya perbedaan terhadap nilai anak di dalam keluarga. Orang tua yang tidak berpendidikan, cenderung menilai anak dari sisi ekonominya, dimana anak dilahirkan dan dibesarkan tidak lain dan tidak bukan untuk membantu orang tua. ${ }^{12}$ Hal ini berbanding terbalik dengan WUS yang berpendidikan menengah yang hanya 40 persen. Hal berarti bahwa, sasaran utama advokai dan KIE program BKKBN adalah masyarakat dengan tingkat pendidikan rendah (tidak sekolah dan Sekolah Dasar). 
Proporsi Jumlah Anak Yang Diinginkan Menurut Tingkat Kesejahteraan, Prov. NTB
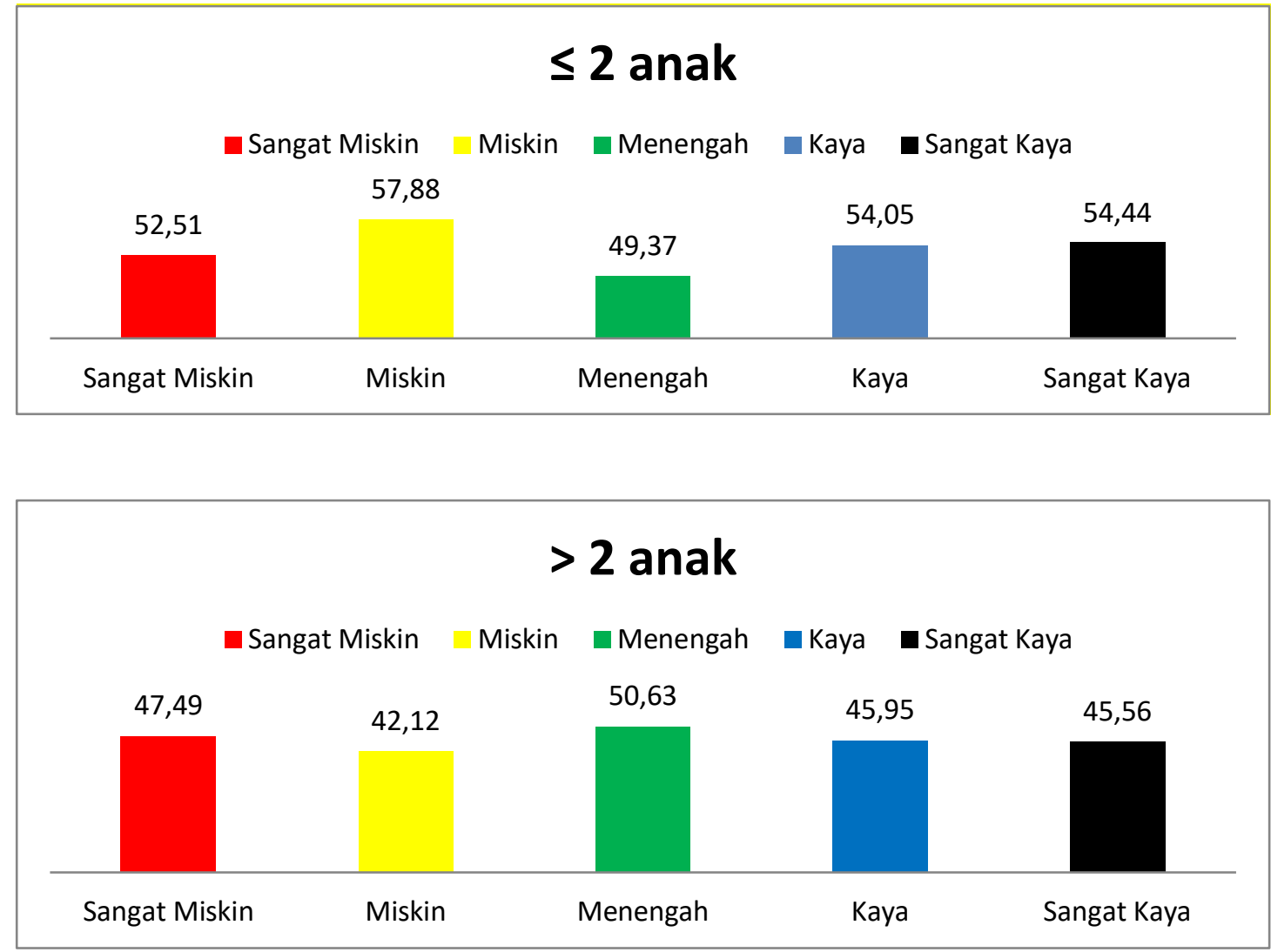

Sumber Data SDKI Prov. NTB yang telah diolah, 2017

WUS yang memiliki kesejahteraan yang rendah maupun tinggi memiliki kecenderungan yang relatif sama terkait jumlah anak yang diinginkan. Hanya WUS yang memiliki kesejahteraan di level menengah yang memiliki kecenderungan menginginkan anak lebih dari 2 yang lebih tinggi.

Keinginan Memiliki Anak

Membatasi jumlah anak yang dimiliki dalam satu keluarga merupakan strategi dalam mengendalikan jumlah penduduk di Indonesia. Salah satu slogan yang telah familiar di masyarakat adalah slogan dua anak cukup.. Di masa orde baru, program tersebut dipandang berhasil menekan angka kelahiran di Indonesia..

Sebagian besar responden menginginkan anak lebih dari dua. Hal ini mengindikasikan bahwa program dua anak cukup masih belum berhasil mengubah mindset masyarakat terkait keinginan untuk memiliki hanya dua orang anak. 


\begin{tabular}{lcc}
\hline Keinginan memiliki anak lebih dari dua & Jumlah & $\%$ \\
\hline Ingin & 1.749 & 65,12 \\
Tidak ingin & 937 & 34,88 \\
\hline Total & 2.686 & 100,00 \\
\hline
\end{tabular}

Sumber Data : Supas Prov. NTB, 2015 yang telah diolah

Daerah tempat tinggal tidak signifikan secara statistik sehingga tidak menyebabkan perbedaan yang nyata dalam hal keinginan memiliki anak lebih dari 2 pada WUS. Di masingmasing daerah tersebut. Ini berarti baik WUS yang tinggal di daerah perkotaan maupuh daerah perdesaan memiliki preferensi yang sama terkait jumlah anak yang diinginkan. Tingkat kesejahteraan tidak signifikan secara statistik mempengaruhi jumlah anak yang diinginkan oleh WUS, artinya WUS yang berlatar belakang tingkat kesejahteraan tinggi hingga rendah memiliki kecenderungan atau preferensi yang relatif sama terkait jumlah anak yang diinginkan.

Tingkat pendidikan WUS berpengaruh yang signifikan terhadap preferensi jumlah anak yang diinginkan. WUS dengan tingkat pendidikan rendah mempunyai kecenderungan 1,7 kali dibandingkan dengan yang berpendidikan tinggi dalam hal memiliki anak lebih dari dua. ${ }^{5}$

Pereferensi WUS terhadap jenis kelamin anak berpengaruh signifikan terhadap preferensi jumlah anak yang diinginkan. WUS yang memiliki preferensi kepada anak perempuan memiliki kecenderungan menginginkan anak lebih dari 2 sebesar 15 kali lipat dibandingkan dengan WUS yang menginginkan jumlah anak laki-laki sama dengan perempuan. Demikian juga dengan WUS yang memiliki preferensi kepada anak laki-laki juga memiliki kecenderungan yang lebih tinggi menginginkan anak lebih besar dari 2 sebesar 20 kali lipat. Hal ini bahwa WUS yang memiliki preferensi jenis kelamin memiliki kecenderungan menginginkan anak lebih banyak dibandingkan dengan WUS yang tidak memiliki preferensi jenis kelamin. Apabila orang tua lebih suka anak laki-laki atau perempuan, maka upaya untuk membentuk keluarga kecil sejahtera diperkirakan akan mengalami kendala. Orang tua yang hanya mempunyai anak laki-laki saja akan terus berupaya mendapatkan anak perempuan dan sebaliknya. Sehingga akan tercipta keluarga besar dengan jumlah anak yang lebih banyak. ${ }^{3}$

WUS yang tidak bekerja memiliki kecenderungan yang lebih tinggi dalam hal jumlah anak yang diinginkan lebih dari 2. WUS yang bekerja umumnya menginginkan jumlah anak yang lebih sedikit dibandingkan dengan WUS yang tidak bekerja. WUS yang bekerja memiliki kecenderungan 0,7 kali WUS yang tidak bekerja dalam hal keinginan memiliki anak lebih dari 
2. Hal ini disebabkan karena WUS yang bekerja memiliki keterbatasan waktu untuk mengurus anak yang lebih banyak.

\section{Kesimpulan}

WUS di NTB yang telah memiliki dua anak sebagian besar masing menginginkan anak yang ketiga. Semakin lama ibu menikah dan semakin tua usia ibu, kecenderungan untuk menambah anak lagi setelah memiliki dua anak semakin berkurang. Penggunaan KB dan daerah tempat tinggal menunjukkan adanya perbedaan dalam hal keinginan untuk menambah anak lagi setelah memiliki dua anak

\section{Daftar Pustaka}

1. Apriyanti. 2014. Hubungan Tingkat Pendidikan Dan Nilai Anak Dengan Fertilitas Pasangan Perkawinan Usia Muda. Tesis Pascasarjana Pendidikan IPS Fakultas Keguruan Dan Ilmu Pendidikan, Universitas Lampung.

2. BPS Provinsi NTB, 2015. Raw Data Survey Penduduk Antar Sensus (SUPAS) Provinsi Nusa Tenggara Barat Tahun 2015.

3. Dinny Fitri Indah Lestari1, Adnan Haris Musa2, Juliansyah Roy. Faktor-faktor yang mempengaruhi jumlah kelahiran. Inovasi, 14 (1) 2018, 8-19 http://journal.feb.unmul.ac.id/index.php/INOVASI

4. Kingsley Davis dan Judith Blake, 1956. The Social structure and fertility: an analytic framework.

5. Oktriyanto1, dkk, 2015. Nilai Anak Dan Jumlah Anak Yang Diinginkan Pasangan Usia Subur Di Wilayah Perdesaan Dan Perkotaan . Badan Kependudukan dan Keluarga Berencana (BKKBN) Pusat, \& Program Studi Ilmu Keluarga dan Perkembangan Anak, Sekolah Pascasarjana, Institut Pertanian Bogor, Bogor . Jur. Ilm. Kel. \& Kons., Januari 2015, p : 1-9 Vol. 8, No. 1 ISSN : 1907 $-6037$

6. Ronald D. Lee \& Rodolfo A. Bulatao Diterjemahkan. "The Demand for Children: A Critical Essay" dalam Bulatao \& Lee (Ed.), Determinants of Fertility in Developing Countries Volume 1 Supply and Demand for Children, Academic Press, 1983, London

7. Vandenheuvel, A. McDonald, P. 1994. Marriage and Divorce, on Beginning Population Studies. Australia : Australian National University.

8. SDKI. 2012. Survei Demografi Dan Kesehatan Indonesia. Jakarta

9. Singh, H. K, Singh, R. D., Singh, G. P., \& Kumar, A. (2010). Influence of sex composition on demand of child in uttar pradesh. Indian Journal of Preventive \& Social Medicine, 41(1 \& 2), 5766

10. Suyono, H., Soedarmadi, M., \& Noerdin, M. (2013). Menyegarkan pembangunan kependudukan di Indonesia: Akseptor KB membangun keluarga sejahtera. Jakarta, ID: Damandiri.

11. Rahayu, M. L. E. E. (2009). Analisis faktorfaktor yang memengaruhi jumlah anak yang diinginkan oleh Perempuan Usia Subur (PUS) yang bekerja dan pengaruhnya terhadap pendapatan rumah tangga: studi kasus si Kecamatan Taman Kota Madiun. Jurnal Sosial, 10 (1), 72-78.

12. Aditya, A.N. 2011. Hubungan Tingkat Pendidikan dengan Persepsi Orang Tua terhadap Nilai Anak dalam Keluarga di Kelurahan Argasoka Kecamatan Banjarnegara Kabupaten Banjarnegara Tahun 2010. Tesis. Universitas Negeri Semarang 